\title{
Jacek Kaczmarek
}

\author{
Uniwersytet Łódzki
}

Instytut Geografii Miast $i$ Turyzmu

e-mail: jacek.kaczmarek@geo.uni.lodz.pl

\section{Drogi myślenia w geografii społecznej}

\begin{abstract}
Zarys treści: Geograf próbuje wyjaśnić relacje przestrzenne w przyrodzie i w środowisku społecznym. Z kolei geografię można określić jako „sztukę czytania przestrzeni”. Dla geografa środowisko geograficzne to książka, którą próbuje odczytać, poznać jej treść, znaczenia, symbole i relacje między obserwowanymi wydarzeniami. Aby odczytać przestrzeń, potrzebna jest intuicja, wykraczająca poza istniejące schematy, poczucie piękna i nieograniczona wyobraźnia, swoboda myślenia oraz wrażliwość na innych ludzi. Dlatego należy dążyć do przekraczania granic nauki i tym samym umożliwić odkrycie sensu ludzkiej egzystencji w społeczeństwie. Myślenie geograficzne jest kluczem do wyjaśnienia otaczającego świata (naturalnego i społecznego), a przez to zrozumienia miejsca zajmowanego przez człowieka na Ziemi. Tym samym myślenie geograficzne zmierza do poznania prawdy o człowieku, o istocie terytorialnej zanurzonej w rzece czasu.
\end{abstract}

Słowa kluczowe: egzystencja, esencja, doświadczenie, geografia bezpośrednia, moment istotnościowy

\section{Teza}

Polska geografia społeczna pozostaje w stanie uśpienia. Miarą głębokości snu geografów jest brak reakcji na zjawiska dziejące się na scenie współczesnego świata. Badacze środowiska społecznego dziwią się coraz mniej. Nie bywają zaskoczeni drobiazgami, które co krok podsuwa im życie. Otoczenie, środowisko życia geografów staje się nieubłaganie powolną rutyną codzienności. Badacze nie potrafią dostrzec niespodzianek czyhających na nich tuż za progiem ich gabinetów. Zadaniem nauki jest niewątpliwie wyjaśnianie i prognozowanie zjawisk przebiegających w otaczającym nas świecie. Ale aby wyjaśniać jakąkolwiek realność, trzeba najpierw dostrzec to coś, co wymaga wyjaśniania. Warunkiem badania musi być najpierw zauważenie. Wszak wszelkie postępowanie badawcze płynie z naszego doświadczania rzeczywistości. A współczesny geograf już nie wyrusza w teren. Nie przygotowuje się do rozpoczęcia drogi poznawania świata. Badacz już nie pragnie spotkać niewidzialnego i niewyjaśnionego w świecie naszego życia. On zasiada do odkrywania prawdy w wygodnym gabinecie uniwersyteckim. Najlepiej 
czuje się tam, gdzie inni naukowcy zdziałali już wiele. Wtedy można korzystać do woli z zasobów internetowych zapełnianych przez innych systematycznych, seryjnych badaczy. Nowe, puste, powtarzalne zasoby raczej przerażają. Samodzielność i oryginalność sądów ontologicznych nie są obecnie cenione. Geografowie nie otwierają już okien wiedzy i nie bywają zdumieni zmiennością płynącego życia. Uczeni zatracili gdzieś naturalne, proste zadziwienie. Nawet już nie kształcą studentów, tylko ich zniekształcają. Wszak uniwersytety zatraciły gdzieś ducha wspólnego, wolnego poszukiwania prawdy. Zamiast imion i nazwisk używamy liczb, które są miarą produkcyjności naukowej. Te dane są naszymi identyfikatorami. Najłatwiejsze i najatrakcyjniejsze naukowo są drogi doświadczenia przemierzane już licznie przez innych geografów. Nie oczekujmy zatem, że spotkamy geografów na barykadach zmian społecznych. Oni w napięciu wsłuchują się $\mathrm{w}$ pukanie losu do drzwi ich gabinetów. Słyszą bowiem owe genialne cztery dźwięki z początku piątej symfonii Beethovena. Ale słuch zazwyczaj ich zawodzi. To nie los powinien pukać do naszych drzwi (jak powszechnie się sądzi, popadając $\mathrm{w}$ rutynowe odczytywanie dzieł genialnych artystów). To my mamy moralny obowiązek epistemologiczny wkraczania na scenę świata, i te wspomniane cztery dźwięki są krokami badacza rozpoczynającego drogę własnego myślenia. To świat powinien usłyszeć te kroki. Niestety niewielu badaczy dostrzeże to wezwanie do wyruszenia w drogę zapisane przez Beethovena. Większość pozostanie w swoim bezpiecznym gabinetowym świecie. Należy porzucić ten bezpieczny świat i poszukać tego, czego jeszcze nie znamy - lepiej iść na milongę niż do apteki po antydepresanty.

W swojej refleksji nad drogami myślenia w geografii społecznej chciałbym ukazać konieczność zauważenia tego, czego nie zobaczyli jeszcze inni. Chciałbym zwrócić uwagę na formułowanie kreatywnych pytań. Najpierw musi być pytanie, aby poszukiwać odpowiedzi. Moim zdaniem pytanie jest ciekawsze niż odpowiadanie na nie. Sformułowanie pełnej odpowiedzi bez wątpienia jest pożądane w nauce, kończy jednak drogę odkrywania. Wtedy osiągamy kres poszukiwania, a problem zawarty w pytaniu zostaje rozwiązany. Czyli mniej będzie o konkretnym warsztacie badawczym, więcej natomiast o „niewiedzy”, niż o tym, co znane i ugruntowane w zakresie narzędzi i technik badawczych. Interesuje mnie także bezpośrednie doświadczanie rzeczywistości i udział w uzasadnianiu nauki, czyli kwestia, dlaczego geografów nie ma na barykadach zmian społecznych. Ponieważ to nie oni rozniecają światło wiedzy, ale lecą do ognia rozpalanego przez zarządzających nauką. Ów atawizm prowadzi do samospalenia. Zadaniem badaczy powinno być dostrzeganie niezauważanego. Odsłonięcie niewidzialnego bywa właśnie wydobywaniem z ciemności. Staje się oświetlaniem prawdy. Do tego, co było zakryte, badacz powinien przynieść roznieconą pochodnię. Podstawowym motywem w odsłanianiu niewidzialnego jest ciekawość. To ona prowadzi do odkrywania istoty analizowanej rzeczywistości. Nie można zgodzić się z powiedzeniem, że ciekawość jest pierwszym stopniem do piekła. Bez ciekawości nie byłoby nauki. Być może Adam był prekursorem badań naukowych. On to bowiem przekroczył granicę ciekawości i zerwał owoc z drzewa poznania dobra i zła. Nasz praojciec zapragnął wiedzieć, a ceną za pożądanie wiedzy 
było wygnanie $z$ raju. Od tysiącleci badacze pokutują za ten grzech ciekawości, a w konsekwencji zdobywania wiedzy o świecie. Współcześnie badaczom zaczyna brakować tej determinacji wyjaśniania świata. Naukowcy już nie rzucają na szalę swej rajskiej egzystencji. Tej ciekawości poznawania, odkrywania zaczyna brakować. Badacze cenią sobie spokój w wyraźnie zadekretowanych dyscyplinach. Lepiej pozostać w ciemności, niż włączyć lampę, która oświetla miejsca znajdujące się za ścianą wyobraźni. Ową ścianą są podziały wyznaczone pomiędzy dyscyplinami. A badaczom zaczyna brakować odwagi, aby zajrzeć poza rzeczywistość zadekretowaną w ustawach i w rozporządzeniach. Obowiązkiem badacza jest wydobywanie nieznanego $z$ cienia. Niezbędne $w$ tym postępowaniu jest światło włączone przez badacza. Ale ziarno poszukiwanej prawdy badacz musi mieć w sobie. Dobrym drogowskazem jest fragment 51 Psalmu w tłumaczeniu Czesława Miłosza (1981): „Ty żądasz, abym miał prawdę w głębi serca, w ukryciu uczysz mnie mądrości" (Ps 51, 8). Zatem wyruszamy w drogę odkrywania mądrości i poszukiwania prawdy (Kaczmarek 2017). Są to bowiem zadania fundamentalne w każdej drodze badawczej. A niestety nauka przestaje myśleć i szuka warunków wygodnego i dostatniego życia.

\section{Uzasadnienie}

Moje drogi myślenia poprzedza egzystencja, czyli doświadczanie biegu życia i powtarzalnej codzienności. Życie i jego smakowanie pozwala dostrzec obietnicę prawdy. Aby istota bycia została odkryta, najpierw musi być przeżyta. Zatem w moich geograficznych drogach myślenia w pierwszej kolejności potrzebne jest życie, czyli bycie w świecie. Aby zrozumieć życie, trzeba najpierw go doświadczyć. Przez doświadczenie własnej egzystencji możemy dotrzeć do sedna badanej rzeczywistości. Można założyć, że egzystencja odsłania esencję. Wędrowanie sugerowaną drogą bywa możliwe wówczas, kiedy nauka idzie przez poznawany świat w parze ze sztuką. Taki mariaż jest niezbędny, sam umysł nie jest w stanie dostrzec istoty bycia. Dzięki sztuce jesteśmy w stanie zakreślić niewidoczne. Ono staje się dostrzegalne na drodze artystycznego myślenia. Dopiero to, co zostało odsłonięte, nauka może wyjaśnić. Takie jest bowiem jej zadanie. Natomiast współczesna nauka niewiele wyjaśnia. Znów nasuwa się dobrze znana opinia „nauka nie myśli”. Dlaczego brakuje geografów na barykadach postępu społecznego? Otóż współczesna geografia nie wyjaśnia, nie przyczynia się do odsłonięcia niewidzialnego. Współczesna geografia zazwyczaj opisuje widzialne. Miarą osiągnięcia naukowego stała się bowiem liczba porządkowa, a sens myślenia zostaje zasypany przez spadający gruz rekonstruowanego gmachu organizowania sposobów uczenia się. Współczesny geograf opisuje to, co już widać, i także inni już to zauważyli. Nie jest ważna oryginalność, ponieważ może być ona niebezpieczna. Opłacalna jest powtarzalność i seryjność. Nawet taśma produkcyjna Forda z 1913 r. była ciekawsza od seryjnego wytwarzania produktów naukowych. Skoro - zgodnie z przyjęta tezą - bezpośrednie doświadczanie indywidualnej egzystencji odsłania istotę bycia, a esencja współczesnej geografii jest mizerna, zatem 
egzystencja współczesnych geografów też jest nijaka. Kiedyś pisano o „znijaczonej przestrzeni”. Teraz można pisać o znijaczonym przebywaniu w przestrzeni. A drogi myślenia kruszą się pod wpływem rozmaitych erozji. Także nijaczeją.

W naukach społecznych kluczową rolę odgrywa poznawanie i odkrywanie nieznanego przez indywidualny, myślący podmiot. Badacz zbliża się do tajemnicy świata. To badacz dokonuje pomiaru, wyciąga wnioski, formułuje prawidłowości. Naukowiec czyni sobie ziemię poddaną, to on mierzy rzeczywistość. Nie oznacza to, że człowiek jest podstawową miarą wszechrzeczy, czy geograf jest miarą wszechświata. Doświadczanie świata może prowadzić do odkrywania miary wszechrzeczy. To jest właśnie istnienie, które odsłania esencję. Moja droga może doprowadzić mnie do odkrywania prawdy. To nie jest relatywizacja prawdy. Nie ja jestem miarą prawdy, ale moje życie pozwala do niej dotrzeć. Zatem może być wiele dróg prowadzących do jednego celu, czyli odsłaniania prawdy o wszechświecie, którą można nazwać prawdą geograficzną. Pouczająca jest w tym kontekście treść drugiego listu do Koryntian (4, 17-18): „Niewielkie bowiem utrapienia nasze obecnego czasu gotują bezmiar chwały przyszłego wieku dla nas, którzy się wpatrujemy nie w to, co widzialne, lecz w to, co niewidzialne. To bowiem, co widzialne, przemija, to zaś, co niewidzialne, trwa wiecznie". Odsłanianie niewidzialnego umożliwia dotarcie do trwałej wiedzy. Widoczne, już przedstawione, nie ma nadzwyczajnej wartości, niezależnie od miejsca rankingowego, w którym odnajdziemy publikacje o rzeczach często oczywistych. Zapracowani naukowcy najczęściej zasypiają podczas lektury swoich dzieł, a budzą się niespodziewanie, gdy ktoś cytuje ich pomyłki. Natomiast sami nie są zbyt zainteresowani własnymi odkryciami. Także świat ignoruje ignorantów.

Jakie wobec przedstawionych uwag mogą być drogi myślenia w geografii społecznej? Jakiego kształtu badań geograficznych możemy oczekiwać? Proponuję określenie geografia bezpośrednia. Jest to powrót do źródeł geografii, czyli nauki o życiu człowieka na Ziemi, o jego domu, o formach zróżnicowania kontekstów społecznych. Samo słowo sugeruje opisanie Ziemi, czyli domostwa człowieka. W pierwszej kolejności mamy zatem do czynienia z bezpośrednim doświadczeniem i opisaniem tego życia. Jeżeli geografia ma być nauką, w ramach której konstruowane są ogólne prawa wyjaśniające procesy dziejące się na Ziemi, to pierwszym krokiem musi być bezpośrednia obserwacja. Niestety geografia zagubiła swoje atuty. Bezpośrednia obserwacja terenowa przestała pasjonować badaczy. Wyruszają czasami nieliczni (Kotus 2015), a większość nie próbuje doświadczać badanego środowiska geograficznego. Własny ogląd i doświadczanie rzeczywistości zastąpiły badania ankietowe, np. wartość przestrzeni miejskiej w świadomości mieszkańców. Zalew informacji cyfrowych prowadzi do banalizacji badań. Wielkie liczby służą usprawnieniu snucia gawęd naukowych o procesach społecznych dziejących się w zróżnicowanych przestrzeniach. Odkrywanie zasad wyjaśniających określone klasy zjawisk czy w końcu konstruowanie teorii powinno być wiodącym zadaniem współczesnych geografów. Skończyła się jednak rzetelna robota terenowa, teoretyzowanie popadło $\mathrm{w}$ banał. Zatem popatrzmy na geografię bezpośrednią jako na powrót do źródeł w nowych kontekstach technologicznych. Jednak w pierwszej kolejności badacze powinni przekroczyć 
bariery, jakimi są sami dla siebie. To my sami jesteśmy bowiem największą barierą. Geografowie stają się tacy jak świat, w którym żyją. Szybki „świat na przemiał" to nasza rzeczywistość i badacze także zanurzyli się w tym znijaczonym biegu czasu badawczego. Geografia nie może pozostawać w granicach rzeczywistości i powinna przekraczać dostrzegalny horyzont zdarzeń. Musi oczywiście rzetelnie je badać. Jednak bezwarunkowe uleganie rzeczywistości prowadzi do banalizacji nauki. Zatem geografia musi także przekraczać stabilny, ugruntowany świat. W znanym układzie problem-proces-prognoza niezmiernie ważne jest przekraczanie granic rzeczywistości. Inaczej geografowie pozostaną w granicach zastanego i jarmarcznego świata. A mądrości i prawdy o świecie po prostu zabraknie. Faktyczne doświadczanie rzeczywistości powinno prowadzić do postrzegania nie tylko tej obserwowalnej rzeczywistości. Doświadczanie widzialnego powinno doprowadzać do tego, co pozostaje niewidzialne, czyli tam, gdzie konstytuuje się istota rzeczywistości. W wielu omawianych powyżej kontekstach naukowych niezmiennie ważna pozostaje egzystencja badaczy. Ja, jako podmiot doświadczający otaczającego świata i ta postrzegana rzeczywistość, to tożsamość. Świat bywa rozumiany jako rzeczywistość społeczno-kulturowa, którą człowiek zamieszkuje, eksploruje, poznaje, interpretuje, a nade wszystko konstruuje (Wendland 2011, s. 22). Dlatego też sugestie Wittgensteina (2012) są godne uwagi:

\section{„5.621 Świat i życie to jedno.}

\subsection{Sam jestem swoim światem (Mikrokosmosem)”.}

Podmiot musi być w centrum prowadzonych badań, musi doświadczyć analizowanej rzeczywistości. Badacz obserwuje świat, którego jest częścią. Drogi myślenia, sposoby poznawania mają bez wątpienia podłoże podmiotowe. Zatem dlaczego nauka deprecjonuje rolę badacza, czyli podmiotu w wyjaśnianiu i rozumieniu świata? Nawet bowiem myślenie za pośrednictwem liczb, funkcji, korelacji nie pozbawia obiektywnego, niezależnego, samodzielnego badacza jego podmiotowości. To przecież podmiot formuje cele swojej pracy, dobiera arkusze kalkulacyjne, wprowadza adekwatne algorytmy analityczne. Sam decyduje o kształcie budowanych modeli wyjaśniania badanej rzeczywistości. Dlaczego zatem rezygnujemy w nauce $z$,ja”, czyli podmiotu badającego świat? Warto sięgnąć do myślenia pozostającego w kręgu francuskiej fenomenologii. Michel Henry wskazuje, że fundamentem prawdy jest radykalna subiektywność (Kruszyńska 2018, s. 33). A tę fundamentalną podmiotowość nazywa on życiem fenomenologicznym. Świat jest uwarunkowany podmiotowo jego transcendentalnością, czyli totalnością jego egzystencji, której nie można zredukować tylko do aktywności poznawczej (Kruszyńska 2018, s. 27). Moja egzystencja poszukującego prawdy jest warunkiem dotarcia do esencji analizowanych procesów. Fenomenologia radykalna smakowana na sposób francuski jest obiecującą drogą w badaniach geograficznych. Sam bowiem jestem swoim światem. Wittgenstein (2012, s. 64) nie pozostawia wątpliwości, aby przekroczyć próg własnego domu i aby następnie wyruszyć na wyjaśnianie świata, trzeba w pierwszej kolejności poznać opuszczane domostwo. Zrozumienie własnego życia otwiera prawdopodobieństwo opisania świata. Ale 
podmiot musi samodzielnie wejść na drogę odkrywania prawdy w świecie. Inaczej dotknie tylko powierzchni tego, co nazywane bywa nauka, natomiast nie będzie badaczem. Jego zmysły pozostaną pozamykane na bodźce płynące ze świata. Święty Paweł pyta w liście do Rzymian, czy wszyscy dali posłuch Ewangelii, czy usłyszeli Słowo rozchodzące się po całym świecie (Rz 10, 16-18): „(...) wiara rodzi się z tego, co się słyszy". Czy geografowie potrafią wsłuchać się w to, w jaki sposób przemawia świat? Czy badacze środowiska społecznego, zorganizowania przestrzeni dostrzegają problemy współczesnej cywilizacji? Czy słyszą wieści napływające ze wszystkich stron, z bliższych i dalszych okolic? Czy są oni ciekawi wydarzeń, o których się mówi tu i teraz, czy też gdzieś dalej: „Jak pełne wdzięku są stopy zwiastuna dobrej nowiny" (Rz 10, 15; Iz 52; 7). Jeżeli popatrzymy uważnie, wówczas dostrzeżemy stopy zwiastujących ważne problemy badawcze. Inaczej brniemy w banalność i powtarzalność. Należy także podkreślić, że wiele jest dróg myślenia o świecie. Wiele jest sposobów odsłaniania prawdy. Ale trzeba bezwzględnie stwierdzić, że wielość metodologiczna prowadzi do jednej Prawdy. Stein napisała w liście, adresowanym w rzeczywistości do Edmunda Husserla: „Kto szuka prawdy, szuka Boga, choćby o tym nie wiedział” (2000, s. 297). Wybieramy wiele dróg myślenia, ale cel ukazuje się jeden - odsłanianie prawdy świata. Niezmiennie istotne pozostaje pytanie o jakość wędrowania, o sens wykorzystywanej epistemologii. Cel jest jeden, ale dróg wiele. Chojnicki (2001) opowiadał się za przyjęciem w geografii społeczno-ekonomicznej (teraz możemy dodać i w gospodarce przestrzennej) modelu naturalistycznego w wersji umiarkowanej. Polega on na rozpatrzeniu dwóch dróg myślenia, tzn. podejścia naturalistycznego i humanistycznego, w ich podstawowych, praktycznych wersjach. Warto powrócić do owej propozycji nurtów badawczych, zastępujących podział na ujęcie scjentystyczne i antyscjentystyczne (Chojnicki 2001, s. 17). Rzeczywiście należało ukazać sens epistemologiczny obu koncepcji, nie obarczając bagażem pejoratywnej konotacji tzw. naukowości i jej braku. W podejściu naturalistycznym wzorcem postępowania są nauki przyrodnicze i metody tam stosowane można wykorzystywać do rozwiązywania problemów społecznych. W podejściu humanistycznym metody nie są najważniejszą kwestią odsłaniania prawdy. Rzeczywistość jest bardziej złożona niż zakładano i nie da się jej wyjaśnić za pomocą modelowania matematycznego. Człowiek w środowisku społecznym nie da się sprowadzić do wartości nadziei matematycznej. W modelu naturalistycznym podstawą obiektywnej wiedzy o świecie są fakty empiryczne. A ostatecznym celem badań geograficznych w nurcie naturalistycznym powinno być odkrywanie praw i budowanie teorii. Natomiast w podejściu humanistycznym nie można pominąć roli podmiotu doświadczającego badanego środowiska geograficznego. Badacz zmierza zatem do określenia podstaw rozumienia analizowanych zjawisk w kontekście świata wartości. Uznając wybór epistemologiczny dokonany przez Zbyszka Chojnickiego, opowiadam się za zintegrowanym modelem pluralistycznym. Nieodzowną drogą odkrycia naukowego $\mathrm{w}$ wariancie pluralistycznym pozostaje konieczność myślenia regułami sztuki. Dzięki nim można dostrzec to, co zazwyczaj bywa niewidzialne dla wielu badaczy. Artysta nie wyjaśni świata, ale pomoże uruchomić wyobraźnię, która jest źródłem odkrycia naukowego. Nauka bez sztuki traci 
wyobraźnię, natomiast sztuka bez nauki bywa bezradna. Nauka i sztuka muszą iść w parze, a każda osobna droga będzie jałowa bądź ślepa. Jak wskazano, celem postępowania badawczego jest odkrywanie prawdy. Możliwości postępowania naukowego jest wiele. Ważne w prowadzonej dyskusji jest następujące sformułowanie: można zaakceptować wiele wariantów myślenia badawczego, ale każde działanie musi być przygotowane i następnie wykonane w sposób sensowny. I nie ma znaczenia, czy kryterium działania pozostaje liczba, czy też słowo. Każdą rzecz trzeba zrobić porządnie. I to jest podstawowe kryterium poprawności naukowej. Rozważania o drogach myślenia w geografii społecznej snują się po szlakach i bezdrożach myślenia o nauce. Brniemy często w przyszłość pod wpływem olśnienia, które odsłania oryginalność nowych podejść. Czasami potykamy się o przeszłość, która odkrywa przed nami karty książek już zapisanych. Bywa, że rewolucyjne zapędy są powtórzeniem wcześniej dyskutowanych koncepcji. Po przypomnieniu koncepcji dualizmu metodologicznego $\mathrm{W}$ geografii społeczno-ekonomicznej opracowanej przez Zbyszka Chojnickiego, warto powrócić do zapisków Martina Heideggera sporządzonych w latach 1936-1938. W rozdziale „Rozbrzmienie” mamy szansę wsłuchać się w wybrzmiewanie prawdy przywoływanej przez Heideggera. W pierwszej kolejności powinniśmy wsłuchać się w wybrzmienie sensu nauk humanistycznych, które „(...) muszą pozostać nieścisłe, aby być rygorystycznymi. Nie jest to ich wadą, lecz zaletą. Nadto zaprowadzenie rygoru nauk humanistycznych pozostaje znacznie trudniej osiągalne niż wyprowadzenie ścisłości nauk ścistych" (Heidegger 1996, s. 144). Przytoczone wskazanie Heideggera należy dołączyć do istotnych cech obu wymienionych podejść w geografii społeczno-ekonomicznej. Dalsza lektura „Przyczynków do filozofii” pozwala dopatrzyć się radykalnej charakterystyki nauki, o której warto pamiętać we współczesnych czasach zamętu: „Wraz z umacnianiem machinacyjno-technicznej istoty wszystkich nauk coraz bardziej będzie maleć przedmiotowa i metodyczna różnica między naukami przyrodniczymi a humanistycznymi. Jedne stają się częścią składową techniki maszynowej i przedsiębiorstw, drugie rozrastają się w obszerną naukę gazetową o ogromnym zakresie (...) "Uniwersytety» jako "miejsca badań i nauczania (w takim kształcie są one wytworem XIX stulecia) stają się czystymi i coraz «bliższymi rzeczywistości» przedsiębiorstwami, w których nic się nie rozstrzyga. Resztkę kulturalnej dekoracji zachowają one tylko dopóty, dopóki będą musiały pozostać jeszcze środkiem propagandy «kulturalnopolitycznej». Nie będzie już można rozwinąć na ich podłożu żadnej istoty «universitas»: po pierwsze dlatego, że w służbie narodowo-politycznej czegoś takiego już nie potrzeba, po drugie zaś, ponieważ samo przedsiębiorstwo nauki daleko pewniej i wygodniej utrzymać w ruchu bez tego, co «uniwersyteckie», tzn. tu po prostu bez woli namysłu. (...) Powyższa charakterystyka "nauki" nie wynika z opozycji wobec niej, ponieważ taka opozycja w ogóle nie jest możliwa. Przy całej swojej dzisiejszej ogromnej rozległości pewności swoich wyników i zasobności, „nauka» nie zawiera w sobie żadnych założeń istotnej rangi, z racji której mogłaby ona kiedykolwiek stanąć w opozycji do wiedzy myślenia. (...) «Nauka» zajmuje się tedy zabezpieczaniem stanu zupełnego braku zapotrzebowania na wiedzę (...)" (Heidegger 1996, s. 149-150). Pogoń za nowością, wstępowanie na barykady postępu 
naukowego bywa ekscytujące. Czasami warto jednak odczytać myśli już niezbyt nowe, ale niezmiennie oryginalne. Mamy zatem problem nie z podziałem nauk, ale $z$ istotą pracy naukowej. Powinniśmy powtórnie odsłonić istotę pracy badawczej. Rozwiązanie tej kwestii ponownie nie będzie nazbyt nowatorskie. Otóż trzeba powrócić do wartości i należy przyznać należytą rangę indywidualnemu podmiotowi odpowiedzialnemu za prowadzenie badań. Obiektywnego, niezależnego badacza nie można pozbawiać osobowości. W rozważaniach o drogach myślenia W geografii społecznej nie można pominąć oceny rzeczywistości otaczającej nas badaczy, obywateli. Żyjemy niewątpliwie w czasach zamętu aksjologicznego. Według Tadeusza Gadacza: „Czasy zamętu polegają też na tym, że jeśli nawet myślimy o wartościach, to nasze życie ograniczyło się w dużej mierze do świata przedmiotowego, do posiadania, do wartości najniższych (hedonicznych, utylitarnych, witalnych). W ten sposób świat przedmiotowy przesłania nam świat wartości wyższych, duchowych (moralnych, estetycznych, religijnych). Żyjemy w swoistym zaćmieniu wartości wyższych, które rozstrzygają o tym, kim jesteśmy, a nie o tym, co posiadamy" (Gadacz 2010, s. 28). Myślenia w kategoriach wartości istotnych nie można zaliczyć do najnowszych. Wszak w księdze Koheleta czytamy od wieków o marności nad marnościami. Badacze także gonią wiatr, który wieje, kiedy chce i kędy chce. W czasach zamętu porzucono namysł nad światem i kondycją człowieka. Częściej produkujemy informacje niż odkrywamy prawdę, wzbogacając tym samy skarbnicę domniemanej wiedzy. Wcześniejsze sugestie badawcze, niezależnie od ich wartości poznawczych, zazwyczaj są ignorowane, gubione w zamęcie poszukiwań przedmiotowych, o czym pisał Tadeusz Gadacz. Zwracano także uwagę, „że geografia społeczno-ekonomiczna uczyniła przedmiotem prowadzonych analiz posiadanie, zdobywanie oraz utratę dóbr materialnych w określonym środowisku geograficznym" (Kaczmarek S., Kaczmarek J. 2010, s. 43). Badanie przestrzeni społecznej eksponuje przede wszystkim konteksty zarządzania i organizacji. Pominięto natomiast kwestie dobra i spotkanie $z$ drugim człowiekiem - sierotą, wdową, żebrakiem. Świat epistemologiczny geografów społecznych odgrodził się od rzeczywistych dramatów dziejących się w przestrzeni miejskiej. Należy jednak wyraźnie zaznaczyć, że obszar badań geograficznych zamknął się na kwestie dobra. Drogi dociekań geograficznych wiodą częściej przez obszary gromadzenia dóbr, a omijają terytoria agatologiczne. Istoty dobra nie znajdziemy w definicjach, w abstrakcyjnych teoriach złożonych w skarbnicy wiedzy. Dobro jest naszą postawą, praktycznym, rzeczywistym działaniem, relacją $z$ drugim człowiekiem. Dobro nie tkwi wyłącznie w słowach uczonych, ono skrywa się w prostych uczynkach. Znaleźć dobro można w ciszy. Ono nadchodzi bez owacji, zbędnych słów, podziękowań. Wydarza się zwyczajnie, wśród nas, bez poklasku. Dlatego, że jest zwyczajnie dobrem. Nadchodzi niepostrzeżenie. Spotkamy je, kiedy jesteśmy przygotowani na takie zdarzenie. Być przygotowanym na spotkanie dobra oznacza praktyczną postawę, nie tylko myślenie bądź mówienie o nim. Metodyczna analiza niewątpliwie porządkuje kwestie dobra, ale nie odkrywa jego sensu. Zatem dobro jest postawą otwartości na przyjmowanie dobra oraz gotowością do darowania dobra innym. Dobro jest relacją z drugim człowiekiem. Nie spotkamy dobra w stanie spoczynku. Domeną dobra jest ruch, czyli 
niezmienna dynamika w przestrzeni dialogu. Nie można po prostu być dobrym. Dobrym jest się zawsze dla kogoś. Przestajemy odróżniać dobro od dóbr. Studia nad światem społecznym nie oznaczają jeszcze władania nim. Czy możemy powtórzyć: „Jak bogi jesteście, wy wszyscy jesteście synami Najwyższego. Ale jak ludzie umrzecie i upadniecie jak upadł każdy z władających" (Ps 82, 6-7)? Pokora jest także ważną cechą postawy badacza, a została pogubiona w czasach zamętu aksjologicznego.

Sensowność roboty naukowej (sprawnego i godnego działania w trosce o prawdę, wg Kotarbińskiego 1975, s. 188) nie ma zastosowania bez otwartości na świat i bez zainteresowania wydarzeniami w nim się dziejącymi. Praca naukowa jest w głównej mierze zbieraniem. Co zbiera badacz? Otóż on zbiera chwile. Chwilę można określić jako przelotny stan zharmonizowania wielu elementów doświadczanych $\mathrm{w}$ badanym świecie. Taka równowaga jest warunkiem odsłonięcia prawdy. Badacz staje się kolekcjonerem takich stanów zharmonizowania, wtedy kiedy one wystąpią i oczywiście zostaną dostrzeżone. Zbieranie chwil zgodności badawczej wymaga cierpliwości i pozytywnego nastawienia do życia. Inaczej owe przebłyski harmonii świata przeminą niezauważone. A może odkrycie nie zależy wyłącznie od badacza? Czyż nie miał racji Kubuś Puchatek, kiedy wspominał, że chwile wybierają podmiot, w którym chcą się zadomowić: „Bo układanie Wierszy i Piosenek to nie są rzeczy, które się łapie w powietrzu. To one cię łapią i wszystko, co można zrobić, to pójść tam, gdzie one mogłyby cię znaleźć" (Milne 1987, s. 125). Niewątpliwie zbieranie chwil musi mieć swoją logikę. Potrzebne jest miejsce, gdzie nowatorskie myśli mogą odnaleźć badacza. Takimi miejscami są po prostu ważne zagadnienia społeczne umiejscowione w konkretnej przestrzeni. W dalszej kolejności powinien pojawić się moment olśnienia, czyli dostrzeżenie niewidzialnego. Owo olśnienie jest możliwe wówczas, kiedy następuje zharmonizowanie myślenia $z$ przebiegiem zjawisk $\mathrm{w}$ doświadczanym świecie. Olśnienie i następnie odsłonięcie mogą doprowadzić badacza do dostrzeżenia istoty obserwowanych procesów. To chwila uzasadnienia prawdy, to znaczy kolejny krok do sformułowania prawa, czyli wyjaśnienia przebiegu określonej klasy zjawisk. Ten ostatni etap myślenia badawczego można określić mianem momentu istotnościowego. Idea istoty badanych zjawisk została wybrana spośród licznych opracowań fenomenologicznych. Otóż wspominana już Edyta Stein dostrzegła niedostateczny zakres wyjaśniania w platońskich ideach: „Arystoteles zdecydowanie odmówił ideom samodzielnego istnienia i ciągle ponawiał wysiłki, ażeby wykazać ich niemożliwość. Jednak i on - choć inaczej rozumiejąc sposób ich istnienia i stosunku do rzeczy - przejął je przecież pod nazwą prawzoru lub formy. Na określenie tych tworów nie będziemy używać dyskusyjnej i wieloznacznej nazwy idei, lecz fenomenologicznego wyrażenia moment istotnościowy. Jest wiele przeżyć radości: różnią się one tym, że są przeżywane przez rozmaite Ja, rozróżnia je ich przedmiot, ich określoność czasową i okres trwania, itp. Moment istotnościowy - radość - jest jeden. Nie jest on mój, ani twój, nie jest teraz czy później, nie trwa długo czy krótko, nie istnieje w przestrzeni i w czasie. Ale zawsze tam, gdzie przeżywa się radość i zawsze wtedy, kiedy się ją przeżywa, urzeczywistnia się radość jako moment istotnościowy" (Stein 1995, s. 97). Wtedy pojawia się 
szansa odsłonięcia Prawdy, czyli zobaczenia istoty badanych procesów. Wybór dróg myślenia nie pozostaje tylko autonomiczną decyzją badacza. Funkcjonuje on w otoczeniu instytucjonalnym, które wyznacza zakres prowadzonych prac naukowych. W skrajnych przypadkach, w ustroju autorytarnym, nie ma możliwości wyboru dróg myślenia. Własne wybory, niezależne postępowanie empiryczne zostaje podporządkowane decyzjom administracyjnym. Idziemy tam, dokąd wolno chodzić. Granice dyscyplin naukowych stają się barierami myślenia. Prawda, dobro, piękno zostają zadekretowane do właściwych obszarów opisywania rzeczywistości. Prawda i wolność są tylko hasłami wypisanymi na mocno już przykurzonych sztandarach. Geografowie nie wychodzą zatem na barykady. Oni chowają się za barykady, które ktoś już poustawiał. Bywa, że badaczom odbiera się nie tylko autonomię epistemologiczną, ale „okrada się ich z samych siebie” (Schmidt 2018 , s. 224). I badacze wchodzą w role nie twórców, ale wytwórców. Badają świat dla produkcji kolejnych, powielanych opisów świata. W efekcie mamy do czynienia z nadmierną podażą produktów naukowych. Nadmiar czegokolwiek na rynku powoduje deprecjację dostarczanych towarów i usług. Ich wartość rynkowa spada. Taki jest świat wytworów współczesnej nauki. Produkujemy coraz więcej, dla szybszej konsumpcji i sprawnego zużywania. Po oceanach pływają nie tylko wyspy plastikowych śmieci, ale po oceanach naszej kultury pływają wyspy odpadków współczesnej nauki.

\section{Konkluzja}

Krytyczne rozważania o kondycji geografii społecznej oraz stosowanych metodach badawczych nie należą do przedsięwzięć najnowszych. Popatrzmy jednak wokół siebie, nie poprzestając na założeniach tej jednej dyscypliny badawczej. Otóż można bez specjalnego ryzyka stwierdzić, że geografia społeczna ma się dobrze poza geografią. Zwrot topograficzny dokonany przed wielu laty w naukach humanistyczny już nie wywołuje ekscytacji czy po prostu zdziwienia. Podejście przestrzenne jest powszechnie akceptowane i stosowane $w$ różnych dziedzinach badań nad człowiekiem i jego światem symbolicznym czy praktykami codziennymi. Podejście topograficzne stało się fundamentalnym założeniem geopoetyki, czyli jednego $z$ nurtów interpretacyjnych $\mathrm{w}$ nowoczesnym literaturoznawstwie (Konończuk, Sidoruk 2015). Bogactwo koncepcji geograficznych oraz ich świeżość oglądu rzeczywistości zachwyciły humanistów. Korzystają oni z dorobku geograficznego o zróżnicowanej proweniencji (Konończuk i in. 2014). Bez zrozumienia kontekstów geograficznych nie byłoby wiodących koncepcji interpretacyjnych w teoriach i praktykach literackich (Rybicka 2014). Powtórzmy, geografia społeczna ma się dobrze poza wąskimi granicami dyscypliny. Tylko w awangardzie nauk humanistycznych trudno spotkać geografów. Na barykadach postępu naukowego spotkamy humanistów odkrywających koncepcje geograficzne, a geografowie gdzieś wyszli lub posnęli, jak uczniowie w Getsemani. Nie będzie zbyt oryginalnym odkryciem wskazanie, że potrzebne jest budowanie mostów epistemologicznych. Zamykanie się w obrębie własnych obszarów badawczych 
prowadzi do schizofrenii ontologicznej. Kto wsłucha się uważnie w dwa ostatnie uderzenia na nutach $a$ i es „Źródła Aretuzy”, kto podejmie namysł nad sentencją: „Dwumian Newtona jest równie piękny jak Wenus z Milo”, ten otwiera się na prawdę bycia człowieka. Odrzucenie wrażliwości humanistycznej spowoduje zamknięcie się w obrębie rutynowej i powtarzalnej geografii społecznej, w której geografowie nie badają, tylko komunikują.

Myśli zaprezentowane $\mathrm{w}$ powyższych rozważaniach nie są nowe, ale nie są na pewno pogonią na oślep za wszelaką nowością. Są one powrotem do zapominanych rzeczy użytecznych - osady ignorancji stopniowo pokrywają rzeczy użyteczne i wartościowe. Co zatem jest potrzebne geografom społecznym? Zabrzmi to paradoksalnie, ale konieczne staje się uproszczenie myślenia. Badacz, podmiot poznania, musi wyjść $\mathrm{w}$ teren i musi zacząć myśleć, według obserwacji, zmysłów i rzeczywistego dziania się świata. Geograf, podmiot postępowania badawczego, musi być odpowiedzialny za podejmowane decyzje empiryczne i ogłaszane wnioski. To muszą być jego myśli - ja myślę, ja analizuję. Nie powinno pojawiać się jakieś „ano”, czyli myślano, dokonano, przygotowano, itp. Upodmiotowienie geografii społecznej należy uznać za ważny cel nadchodzących czasów. Poza tym geograf nie powinien myśleć tylko pojęciami. Potrzebna jest własna obserwacja i jednocześnie odpowiedzialność za samodzielnie podejmowane decyzje badawcze i słowa wypowiadane, a wywiedzione $z$ oryginalnych, samodzielnych prac terenowych. Geografowie nie mówią własnym językiem, a stosowane metody i używane pojęcia są zapożyczone i naśladowcze.

Co pozostaje geografom społecznym i zaprzyjaźnionym badaczom $z$ innych dziedzin? Powróćmy do słowa, które wielokrotnie ratowało człowieczeństwo od zatracenia. Pozostaje mieć nadzieję. Bywa ona ufnością, czyli poczuciem pewności w urzeczywistnianiu się darowanego dobra. Nadzieja nie przychodzi jednak sama z siebie, nie wydarza się przypadkowo. Nadzieją człowiek zostaje obdarowany. Ten wspaniały podarunek nie może stać się tylko naszą, indywidualną własnością. Darowaną nadzieją trzeba się dzielić z innymi. Otrzymane dobro powinno zostać pomnożone, nie może być zamknięte $w$ granicach jednostkowego egoizmu. Należy podzielić się otrzymanym darem nadziei z innymi, którzy pogubili ufność na ścieżkach życia. Otrzymane talenty powinny przynosić zysk, a będzie nim darowanie dobra drugiemu człowiekowi. Dobro okazane innemu pozwala osiągnąć zysk z otrzymanego daru. Takie zadanie stoi przed geografią społeczną opartą na podstawach aksjologicznych - pomnażanie darowanego dobra poprzez dzielenie się nim.

\section{Literatura}

Chojnicki Z. 2001. Dualizm metodologiczny w geografii społeczno-ekonomicznej. [W:] H. Rogacki (red.), Koncepcje teoretyczne i metody badań geografii społeczno-ekonomicznej i gospodarki przestrzennej. Bogucki Wydawnictwo Naukowe, Poznań, s. 17-25.

Gadacz T. 2010. Wartości w czasach zamętu. [W:] M. Madurowicz (red.), Wartościowanie współczesnej przestrzeni miejskiej. Uniwersytet Warszawski, Warszawa, s. 17-30. 
Heidegger M. 1996. Przyczynki do filozofii (Z wydarzania). Przekład B. Baran, J. Mizera. Wydawnictwo Baran i Suszyński, Kraków.

Kaczmarek J. 2017. Mądrość jako rozumienie świata. Acta Universitatis Lodziensis, Folia Geographica Socio-Oeconomica, 27: 43-56.

Kaczmarek S., Kaczmarek J. 2010. Aksjologia przestrzeni miejskiej - w stronę geografii moralności. [W:] M. Madurowicz (red.), Wartościowanie współczesnej przestrzeni miejskiej. Uniwersytet Warszawski, Warszawa, s. 31-45.

Konończuk E., Nofikow E., Sidoruk E. (red.), 2014. Geografia i metafora. Wydawnictwo Uniwersytetu w Białymstoku, Białystok.

Konończuk E., Sidoruk E. (red.) 2015. Przestrzenie geo(bio)graficzne w literaturze. Wydawnictwo Uniwersytetu w Białymstoku, Białystok.

Kotarbiński T. 1975. Hasło dobrej roboty. Wiedza Powszechna, Warszawa.

Kotus J. 2015. Turyści w strukturze miasta: obraz konfliktu czy koegzystencji? - rozważania na podstawie badań city users w dwóch miastach. Studia Regionalne i Polityka Regionalna, 31: 33-46.

Kruszyńska S. 2018. Kulturalny barbarzyńca. Fenomenologia radykalna Michela Henry’ego jako filozofia sztuki życia. Universitas, Kraków.

Księga psalmów. 1981. Tłum. z hebrajskiego Cz. Miłosz. Éditions du Dialogue, Paris.

Listy Nowego Testamentu w przekładzie z języka greckiego. 2000. Pallotinum, Poznań.

Milne A.A. 1987. Chatka Puchatka. Przekład I. Tuwim. Książka i Wiedza, Warszawa.

Rybicka E. 2014. Geopoetyk. Przestrzeń i miejsce we współczesnych teoriach i praktykach literackich. Universitas, Kraków.

Schmidt V. 2018. Trylogia tekstylna. Przekład uczestnicy warsztatów translatorskich w Austriackim Forum Kultury pod kierunkiem Sławy Lisieckiej. [W:] Widoki z okna. Dramaty. T. 1. ADiT, Warszawa.

Stein E. 1995. Byt skończony a byt wieczny, przekład S.I. Adamska OCD, W drodze, Poznań.

Stein E. 2000. Autobiografia w listach, 1916-1942, przekład S.I. Adamska OCD. Wydawnictwo Karmelitów Bosych, Kraków.

Wendland M. 2011. Konstruktywizm komunikacyjny. Wydawnictwo Naukowe Instytutu Filozofii UAM, Poznań.

Wittgenstein L. 2012. Tractatus logico-philosophicus. Przekład B. Wolniewicz. Wydawnictwo Naukowe PWN, Warszawa.

\section{The ways of thinking in social geography}

Abstract: Geography seeks to explain spatial relations in nature and in the social environment. In general terms, geography can be described as "the art of reading the space". To a geographer, geographic environment is a book which he/she is trying to read, its content, the meanings, the symbols and relations between the events. In order to read the space one needs intuition, going beyond existing schemes, the sense of beauty and unrestricted thinking as well as being sensitive to other people. That is why should exceed the borders of science and make it possible to discover the sense of human existence of Earth. Geographic thinking is key to explain the world around (natural and social) and, consequently, to understand the place occupied by man. Its objective is to discover the truth of human being, the inhabitant of Earth.

Key words: existence, essence, experience, direct geography, an essentiality quid 